\title{
CINTIA FARACO, Suapte natura. L'intrinseca forma razionale della natura: Gabriel Vazquez. Milano, Franco Angeli, 2017, 126 pp., ISBN: 9788891752031
}

La Dra. Cintia Faraco es actualmente investigadora y docente de Filosofía Política en el Departamento de Ciencias Políticas de la Università di Napoli Federico II. Ha escrito ya algunos trabajos de interés sobre la segunda escolástica, como el libro Obbligo politico e libertà nel pensiero di Francisco Suarez, Milano, Franco Angeli, 2013 y otros estudios sobre el pensamiento jurídico de los siglos XVI y XVII.

Este libro que aquí nos ocupa versa sobre la forma racional de la naturaleza en Gabriel Vázquez: un análisis que parte desde filosofía teorética (la metafísica, la antropología y la teoría del conocimiento) y llega hasta el estudio del derecho. La autora no sólo persigue desentrañar la arquitectura intelectual de Vázquez, sino también explicitar cuáles fueron sus fuentes.

En el estudio preliminar, el profesor Franco Todescan subraya el papel de Vázquez en la objetivación de la ley. Frente a los elementos subjetivistas que se habían desarrollado especialmente a través de los herederos de Escoto y de Ockham, Vázquez es presentado como un objetivista a ultranza. En este sentido, al tener la ley un valor intrínseco, incluso Dios mismo queda en un segundo lugar, como si fuese un elemento redundante. Para Todescan, esta concepción sería un anticipo de las tesis más conocidas de Grocio.

Este paso definitivo hacia un radical objetivismo ético se manifiesta claramente en su concepción de la ley natural, que es la naturaleza racional del hombre. La lex naturalis, fundamento ontológico del derecho es, al mismo tiempo, la primera regla de acción del ser humano. Esta convergencia entre la lex naturalis y la natura rationalis permite prescindir del carácter imperativo de la ley, puesto que ya constituye, en sí misma, el eje de actuación intrínseca del ser humano. Con ello, se pierde el valor de la lex aeterna, puesto que la ley natural es totalmente racional y plenamente comprensible por la razón, por lo que no es necesario que Dios la sostenga. Es decir, se sostiene por sí misma, al ser la base de obrar humano: la razón es ya el fundamento absoluto de la ética, de la cual participan, de diversa manera, Dios y el hombre. La razón es, en definitiva, el punto de encuentro entre Dios y el hombre, caracterizados ambos por su irreemplazable e invariable racionalidad.

Para algunos, Vázquez sería el máximo oponente del subjetivismo y del voluntarismo, pues dotaría a la razón de tal poder, que incluso Dios y el hombre estarían sujetos a ella. Frente a la idea de que la omnipotencia podía establecer un orden moral y legal contrario a la razón, Vázquez afirma que Dios no puede ir en contra de la razón, y que esta es autónoma de la voluntad de Dios. De ahí el acertado título del libro: Suapte natura, formulación que tanta resonancia tiene también en el ámbito legal.

Hay autores que han visto a Vázquez como uno de los máximos exponentes de la autonomía de la ley natural y un gran paso en su secularización. Otros, como Cintia Faraco, sin negar lo anterior, buscan los orígenes de su doctrina, preguntándose con quién estaba dialogando el jesuita de Belmonte.

A través de los tres capítulos que componen el libro, la autora estudia la idea de razón en Vázquez, para pasar después al tema del acto humano y su expresión en la ley, y concluir con su hipótesis historiográfica. A lo largo de estas páginas, la autora dialoga con muchos de los tratadistas que se han ocupado de Vázquez, muy especialmente con Juan Cruz Cruz, Jacob Fellermeier, Herman von Garssen, Louis Vereecke, el propio Franco Todescan y otros.

Hay un trabajo de Juan Cruz Cruz, «La estructura intencional de la Ley natural, según Vázquez (s. XVI)», Revista española de filosofia medieval, 20 (2013), pp. 121-133, que sería una segunda parte del artículo citado en el libro: «La esencia humana como regla autónoma del obrar moral, según Vázquez (s. XVI)», al que Faraco interpela extensamente. Es muy probable que este trabajo sobre la estructura intencional ayudase a la autora a respaldar y definir sus posiciones, siempre interesantes, bien escritas y con un punto de provocación.

Precisamente, el punto más provocativo del libro sería el tercer capítulo, en el que se pregunta si Vázquez sería, como afirman algunos, el Agustín español. Para Cintia Faraco, Vázquez estaría en deuda con Gregorio de Rimini, cuyas tesis llevaría al extremo. Esta idea ya había sido anticipada por Welzel y por Otto von Gierke. Para Gregorio existía una distinción entre la lex indicans y la lex imperans, mientras que para el jesuita la 
indicación y el imperativo propios de la ley se fundían en la naturaleza racional del hombre, que se inclinaba ya hacia el bien. La autora lo dice claramente: «L'imperium è, cioè, un atto dei intelletto, che solo formalmente si manifesta come voluntas, ma che voluntas non è» (p. 56).

De esta forma, el jesuita se opuso radicalmente a la difusión de las ideas voluntaristas de Escoto y Ockham, afirmando una fundamentación de naturaleza como intrínsecamente racional, muy lejos de las concesiones escotistas de Suárez. Cintia Faraco ha rehuido deliberadamente de cualquier comparación con Suárez y con Molina, si bien resultaría iluminador proyectar algún trabajo en este sentido, especialmente con Molina, pues existen numerosos estudios con una orientación y finalidad similar, como el libro de Antonio Queralt, S.I., Libertad humana en Luis de Molina, Granada, Facultad de Teología, 1977, que permi-tirían una apertura a tesis más generales sobre la forma racional de la naturaleza en el seno de la escolástica jesuítica.

La autora concluye afirmando que si Vázquez «può esser ascritto a un tomismo filo-agostinista, ma con la precisazione che l'espresione 'filo-agostinista' voglia indicare una connessione più diretta con Gregorio e soltanto indiretta al pensiero dell'Ipponate» (p. 122). Se trata de una tesis fuerte, que limita la influencia de los autores del siglo XVI y de la propia Compañía de Jesús en la formación intelectual de Vázquez, y que vincula al jesuita de Belmonte en la avanzadilla del (neo)agustinismo, que tanta influencia tuvo sobre todo en el siglo XVII. Cabría ver si los «vazquistae», los epígonos que tuvo el pensador de Belmonte en el siglo XVII, siguieron las tesis de su maestro.

Hay que señalar, por último, que Cintia Faraco es una autora sutil, atenta siempre a la lectura directa con las fuentes y con un buen dominio de la filosofía, así como también una buena sintetizadora de los estudiosos contemporáneos de la obra de Vázquez. De momento, este libro ha hecho una contribución interesante y bien escrita a los estudios de la filosofía de Vázquez, sin renunciar al examen juicioso de las cuestiones metafísicas y descendiendo a las consecuencias jurídico-prácticas que se derivan de las premisas asumidas. Por todo ello, esta obra Cintia Faraco merece la atención de todos los lectores interesados.

RAFAEL RAMIS BARCELÓ

Universitat de les Illes Balears - IEHM

\section{MARIA ALESSANDRA BILOTTA (ed.), GERARDO BOTO VARELA (intro), XAVIER BARRAL I ALTET (conclusions), Medie-val Europe in Motion. Palermo, Officina di studi medievali, 2018, 441 pp., ISBN: 9788864851068}

Mobilidade e circulação. Estes conceitos dão o mote para os trabalhos reunidos no presente volume, cuja edição ficou a cargo de Maria Alessandra Bilotta, investigadora pós-doutoral do Instituto de Estudos Medievais da Universidade Nova de Lisboa. Sugestivamente intitulado «Medieval Europe in Motion» e subtitulado «The circulation of Artists Images Patterns and Ideas from the Mediterranean to the Atlantic Coast $\left(6^{\text {th }}-15^{\text {th }}\right)$ ) o conjunto de estudos reunidos resulta da conferência realizada em Lisboa em 2013 com o mesmo nome. Reúne 25 trabalhos de investigadores da Península Ibérica, Espanha e França e engloba textos redigidos em diferentes línguas (inglês, francês, português, italiano e espanhol).

Este volume põem a tónica na questão da circulação e na mobilidade na Europa medieval, com especial enfoque no mundo da cultura material, especialmente no que diz respeito à produção manuscrita e artística peninsular. O volume está estruturado em seis capítulos, organizados tematicamente.

A primeira observação que cumpre salientar após a leitura destes textos diz respeito à tipologia da circulação e da mobilidade propriamente dita. Assim, pode-se dizer que a circulação se opera de três formas: movimentação de objetos propriamente ditos (objetos que «migram» de um espaço geográfico a um outro), movimentação de modelos (veiculados pelo deslocamento dos artesãos/artistas que reproduzem/recriam um novo objeto artístico ou pela (re)produção local de artefactos em circulação), e, no caso especifico da cultura 